\title{
The world we live in: A perspective on blended learning and music education in higher education
}

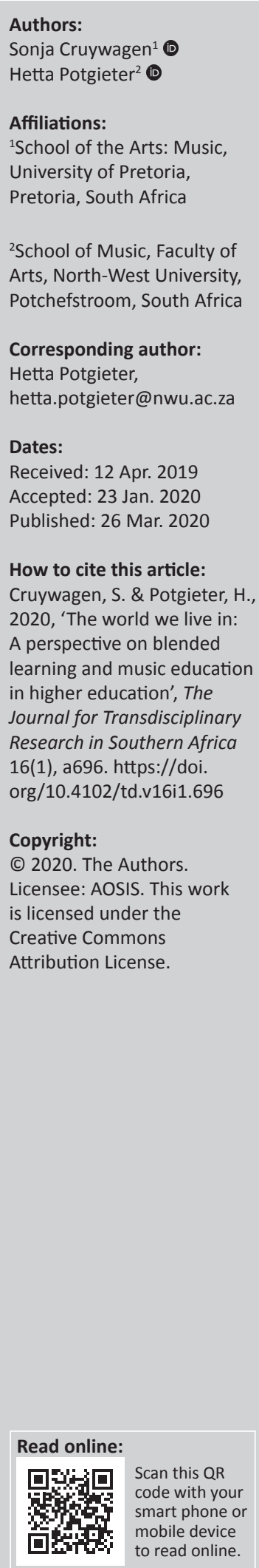

This article investigates the incorporation of Picciano's Blending with purpose multimodal model into an undergraduate music education module. This multimodal model advocates that teachers and instructional designers should use multiple approaches to meet the needs of a wide spectrum of students. The purpose of this intrinsic case study was to understand how the Blending with purpose multimodal model can be applied to facilitate teaching and learning of music education for Bachelor of Music (BMus) and Bachelor of Arts (BA) Music students. The initial reason for conducting this research was to restructure the music education curriculum, which, until 2013, had mostly focused on face-to-face teaching and learning approaches. The use of digital media, which initiated e-learning technologies, changed teaching and learning experiences. Blended learning as the teaching model proved to be a useful and appropriate method in the striving to develop new approaches to teaching and learning in music education. From the interpretation of research findings, a teaching and learning model was created that could be implemented in teaching music in a higher education context.

Keywords: multimodal learning model; hybrid learning; blended learning; music education; tertiary institutions; undergraduate music curriculum; South Africa.

\section{Vignette: Evacuate!}

It is the end of January 2016. Staff members are prepared for the new academic year. They have fresh energy after the December holiday and creative new ideas for presenting lectures. Suddenly a WhatsApp message appears on our cell phones: 'Student protesters attempted to disrupt first-year welcoming. Safety remains the priority. Please leave the campus immediately'. During the following days more and more phone messages of this type were sent by management. The university comes to a standstill for a few days. No first-year welcoming, no classes, no teaching ... for how long? Students are shouting out their frustrations, singing their demands: 'Amalungelo, thina silwela amalungelo wethu' (we are fighting for our rights for... education, food, accommodation etc.). '\#FeesMustFall!'

\section{Why this research?}

The reality of the disruptions at South African tertiary education institutions from 2015 was not the initial motivation for the research, but the findings of this study may now be more relevant and significant after the experiences of tertiary institutions during the \#FeesMustFall campaign.

The research question initially posed for this study was, 'how can the Blending with purpose multimodal model be applied to the teaching and learning of music education (ME)?'. The answer to this question could lead to an understanding that informs the redesigning of ME curricula in national as well as international contexts. For the purpose of this article, the focus was on understanding how the Blending with purpose multimodal model could be applied to complement and supplement the teaching and learning experiences of students in undergraduate ME.

The case studies by Bell-Robertson (2014) and Naughton (2012), as well as a narrative-informed case study by Partti (2014), in which the authors explored musical experiences and creativity in an online community, prompted the idea to delve deeper into this topic. Examples of ethnographical case studies include those by Brändström, Wiklund and Lundström (2012), who examined distance ME, and Waldron (2013), who explained the value of user-generated content in music teaching and learning. Partti (2014) investigated collaborative composing in an online music community using an instrumental case study. Our study complements these studies with research that investigated multiple approaches to online teaching and learning for pre-service music educators. The international relevance of and interest in this issue made it evident that research conducted in South Africa can contribute towards advancing international skilfulness. The process of this research was 
presented at two international conferences of ME International Society for Music Education (ISME) 2014 (Porto Alegre, Brazil) and ISME 2016 (Glasgow, Scotland) at the research commission for ME.

\section{Methodology}

Full-time undergraduate music students who enrolled for ME modules at the University of Pretoria (UP) in 2014 and 2015 were selected as participants. The music students in the ME modules came from different cultural groups. Most students were South African, but there was also one Korean student, a student from Botswana (Tswana) and a student from Malawi (Chewa). The South African students were from Sotho, Tsonga, Afrikaans, English, Greek and Turkish ethnic groups. This study was conducted during the full academic year of 2014 up to mid2015, involving all first-year ME students (22 students - 50-min contact time per week) and all second- and third-year ME students (23 students in total - 100-min contact time per week).

Permission was obtained from the Research Ethics Committee of the Faculty of Humanities, UP, to perform qualitative research involving individuals and groups at the research site for this study. Inviting students to participate in a qualitative interview process was facilitated by the existing relationship of trust (Creswell 2013:Ch. 7) between the interviewer (in this case S.C.) and the interviewees (first-year, second-year and third-year ME students).

Open-ended focus group interviews were conducted for data collection. The interviews focused on how participants experienced the blended teaching and learning in ME at UP to optimise the facilitation of ME at the university in the future. Direct participant observation formed part of the case study (Yin 2009). The participant observer (in this case S.C.) looked at how the participants behaved in multimodal (blended learning) activities to facilitate teaching and learning in ME. Documents, audio-visual material and evidence of student online teaching and learning activities were also used for data collection with participation of all students. These documents included UP course study guides, examples of wikis, discussion board activities and online journal entries.

In order to complete the case analysis, the data were examined through the theoretical lens of Picciano's multimodal model (Figure 1). The relevant theoretical concepts informed the process of coding and theme development (Clarke, Braun \& Hayfield 2015). There were six phases in the thematic analysis: familiarisation, coding, identifying themes, revising themes, naming themes and writing the report (Braun \& Clarke 2006). Data were organised and visually presented in ATLAS.ti 7.1.6 software.

The qualitative strategy for data analysis was thematic analysis. A teaching and learning model was created on the basis of the findings, that is, planning a music education curriculum (Figure 4). The findings of the research are of particular interest for music educators, ME students, research students and curriculum planners in higher education who are exploring different teaching and learning strategies for the future use.

\section{Blending with Purpose - The Multimodal Model}

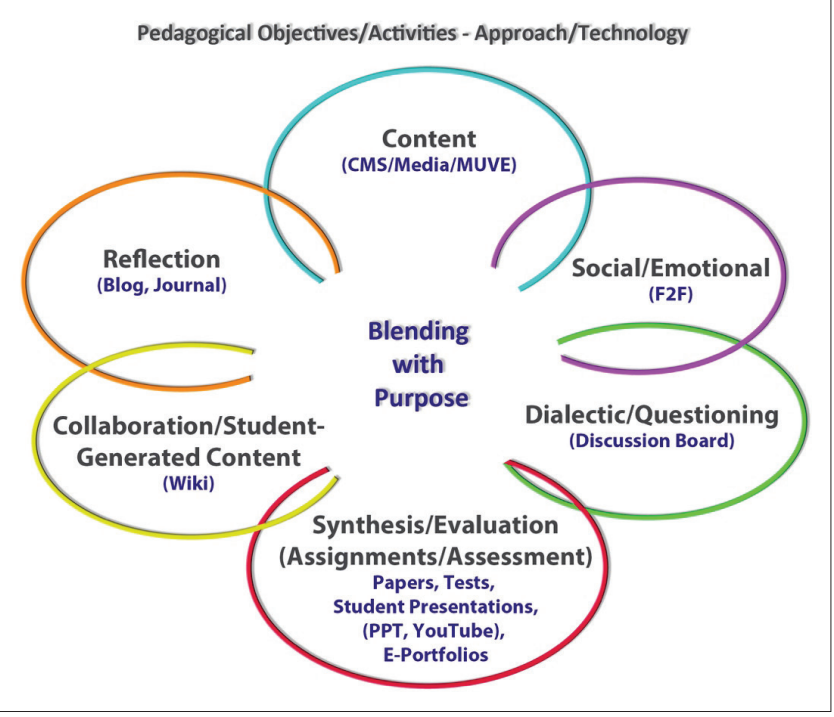

Source: Picciano, A.G., 2009, 'Blending with purpose: The multimodal model', Journal of the Research Center for Educational Technology 5(1), 11.

PPT, PowerPoint; CMS, Content Management Software; MUVE, Multi-user virtual environment; F2F, face-to-face.

FIGURE 1: Blending with purpose multimodal model.

\section{The key challenge}

Currently, approaches to teaching and learning are being challenged by several new philosophies, methodologies (Barell 2010:174-199; Dunbar-Hall 2011:14; Wiggins 2015:1-74) and innovations in learning technologies (Liaw, Huang \& Chen 2007:1066; Long 2005:60; Paechter \& Maier 2010:292; Picciano 2014:35-43). Educators who are educating the first generation of students who have grown up with the products of modern information technologies are challenged to design courses that could develop cognitive skills through technology enhanced pedagogical approaches. Academic programmes need to transfer the 21st-century skills (Carpenter \& Pease 2012:36-41) into the classroom to prepare students to be able to demonstrate their skills in a professional environment. Students need to engage with the environment to construct new understandings through problem-solving experiences (Wiggins 2015:19). Professional environments require skills such as teamwork, self-direction, critical thinking, problem-solving and literacy in the 21st-century information and communications technology (ICT) (Barell 2010:176; Carpenter \& Pease 2012:36-41).

Music educators have to prepare music students to be able to demonstrate these skills in a professional musical environment and to relate to their situation in order to construct new understandings in a holistic context. Garrison and Kanuka (2004:96) refer to the thoughtful integration of classroom face-to-face learning experiences with online learning experiences' as blended learning. ${ }^{2}$ Rovai and Jordan (2004:1) explain that 'blended learning is a hybrid of classroom and online learning that includes some of the

1.C.MS - course management systems, MUVE - Multi-user environments, F2F - faceto-face, PPT - PowerPoint

2.Blended learning also refers to multimodal or hybrid learning. 
conveniences of online courses without the complete loss of face-to-face contact'. Picciano (2009:4) recommends that educators should use multiple approaches that include face-to-face learning as well as online technologies.

Traditional approaches to curriculum design are still adopted in numerous undergraduate music programmes (Kimpton 2005:11; Morford 2007:80). Most undergraduate music programmes include modules such as musicology, theory and analysis, composition, musical performance (Harper-Scott \& Samson 2009:97-218; Morford 2007:75-83) and ME pedagogy (Morford 2007:80). These courses are structured in such a way that the interaction with music occurs through the development of the student's performing and academic abilities, but they do not integrate creative processes to develop competent music educators. The constituent elements of musicology, music theory and performance should intersect in a natural way with what students learn in ME to ensure an integrated view necessary for music educators. Understanding these connections enables students to apply musical understanding to music teaching and learning (Wiggins 2007:36-42). The application of blended learning as a creative teaching strategy to develop technical skills, performance techniques and musical skills are relevant to the world in which students live. Garrison and Kanuka (2004:99) advise that the instructor who plans to accommodate blended learning in a curriculum needs to reconsider and redesign the teaching and learning relationship in a cohesive approach. These challenges are of critical importance and cannot be ignored: 'We are forced, as a result, to consider, once more, the issue of comprehensiveness in education, its meaning and its promise' (Reimer 2007:1).

Multimodal or blended learning faces certain challenges in developing countries that cannot be ignored. Colleagues from the Department of Music and Dance at Kenyatta University in Kenya highlighted some issues that are also applicable to the South African context (Digolo 2012). These include the resistance of lecturers to change from traditional well-known methods of teaching and learning to developing an online pedagogy, a sphere in which they lack experience, confidence, teaching material and assessment criteria; the lack of availability of personal computers with appropriate software programs for lecturers and students; the absence of stable Internet connectivity, which means that slow dial-up speed will hamper ${ }^{3}$ the teaching and learning process. Hence, our curiosity and creative impulses urged us (the authors of this article) to investigate online methodologies that could be implemented at tertiary institutions. $^{4}$

3.Although developed countries do not experience these problems, some African countries are still struggling with Internet connectivity and up-to-date computers and software programs.

4.The research was conducted by Cruywagen (2015) at the Department of Music University of Pretoria. Documents for data analysis included online assignments presented to discussion boards and in journals, research essays and wikis. Lecturers presented to discussion boards and in journals, research essays and wikis. Lecturers from different subject fields at the School of
also involved with online teaching strategies.
Student-centred pedagogical approaches located within the different ways of knowing (Luckett 2001a:55) are characteristic of South African higher education level descriptors. Preparing higher education students for the realities of the working environment is challenging because students come not only from underprivileged educational backgrounds but also from privileged ones (Howie \& Pietersen 2001:7-9; Jaffer, Ng'ambi \& Czerniewicz 2007:134) as well as from higher- and lower-income groups. The school-leaving requirements for admission to first-year university studies have been standardised nationally, but there are many inconsistencies in the standards of basic education in schools (Modisaotsile 2012:1-7). These diverse schooling backgrounds also mean that some music students from private music teaching environments sign up for undergraduate music programme, but they have not studied music as a subject at school. In the light of the above conditions, Luckett (2001b:31) describes four ways of knowing and learning in a proposed epistemically diverse curriculum for South African higher education in the 21st century. These four types develop four fundamental kinds of knowledge of academic disciplines into effective and cohesive reflexive competence:

- Propositional knowledge focuses on foundational competence.

- Practical knowledge focuses on knowing how and learning by doing.

- Experiential knowledge learning takes place through engaging personally and thinking reflectively.

- Epistemic knowledge develops meta-cognition, thinking epistemically, contextually and systemically (Luckett 2001a:55).

\section{Implementation of multimodal learning}

To enrich the integration of classroom face-to-face learning experiences with online learning experiences (i.e. blended learning), Le Rossignol (2014:1-16) propose that specific application combinations should characterise blended learning:

- integration of any online and traditional (face-to-face) learning (Graham 2005:4)

- pedagogical approaches - grounded in learnercentredness (not reliant on learning technologies), for example, constructivism (Scott 2012:191-198; Wiggins 2015:1-41), problem-based learning (Barell 2010:174-199; Wiggins 2007:39)

- different focal points for learning: skills-driven, attitudedriven and competency-driven learning (Valiathan 2002:1-4)

- connections between instructional technologies (media) with different methods of face-to-face learning (Graham 2005:4)

- different web-based technologies in an e-learning environment. 
Several researchers (Merritt 2002; Oblinger \& Oblinger 2005; Salajan, Schönwetter \& Cleghorn 2010; Singh 2014) have studied the characteristics of 'digital natives' (persons brought up with digital technologies who are familiar with computers and the Internet from an early age) and described the values and behaviours of an informationage mindset. The current student generation (Generation Z) grew up in a more technologically advanced environment than the immediately prior generations (Generation $X$ and Generation Y). Emerging Generation Z characteristics are, for example, risk adverse, prematurely mature, pampered and protected (Singh 2014:59).

Komarraju et al. (2011:472) explain that the way in which higher education students relate to new learning information reflect their learning styles and the quality of their thinking, which is critical to learning and could possibly determine their academic success. Pedagogical approaches to undergraduate students (the theory and practice of learning) should incorporate the findings of cognitive scientists on learning styles. These studies have taken into account a number of dimensions of the learning process, including incentives for learning, personality types and the pace of instruction (Picciano 2009:11).

The indications are that multiple approaches that include the adoption of online technology may challenge and stimulate music lecturers and students to experience learning in innovative ways. We realise that scheduled teaching and learning on campuses in South Africa are nowadays often interrupted and education curricula should be restructured to accommodate any change in teaching and learning conditions. Picciano's (2009:11) multimodal model for educators entails the use of multiple approaches, including face-to-face and online technologies.

Picciano's (2009:4-14) multimodal model incorporates multiple perspectives to meet the needs of a wide spectrum of students:

- the sharing of content (e.g. text documents, the Internet links to websites and mashups)

- social/emotional support (e.g. oral communication)

- dialectic/questioning activities (e.g. online discussion boards)

- reflection as pedagogical strategy (e.g. online journals)

- student collaboration to generate content that could be shared (e.g. wikis)

- synthesising, evaluating and assessing learning as objectives.

Jaffer et al. (2007:136) explain that educators have to understand which educational technologies are appropriate for which learning situations. Hybrid learning tools could be used in music classroom to accommodate the collaborative constructivist perspective on ME. Multimodal activities are suitable for text-based research, collaborative learning as well as dialectical/questioning and reflective assignments. The real-life problem-solving learning approaches of creating, listening and performing in ME (Wiggins 2015:57-89) occur primarily in face-to-face sessions.

Students take more responsibility for their own learning (Carpenter \& Pease 2012:37) and develop as learners and individuals by means of participating in a learning community. As active participants in their own learning, students acquire a deeper understanding of content and its meaning (Biggs 1991:27-39; Crosling, Heagney \& Thomas 2009:13; Wiggins 2015:2), participate more effectively in dynamic communication and learn more academic and life skills that could be of their advantage beyond the classroom. Constructivist principles that infuse practice are changing music learning and teaching (Scott 2012), because constructivist learning environments imply that collaborative knowledge and problem-solving outcomes are built on a social level (Jonassen 1999:215-239; Wiggins 2015:24). Inductive approaches that originate in constructivism include inquiry-based and problem-based learning. Inductive methods of teaching adopt a student-centred approach; they require active learning and develop selfdirected learning skills (Barell 2010:174-199; Spronken-Smith 2007:2; Vajoczki et al. 2011:2).

Multimodal learning in undergraduate ME is described, understood and interpreted within a social constructivist worldview. In this intrinsic, single-site case study, the pedagogical objectives and activities of Blending with purpose multimodal model (Picciano 2009:4-14) provided the theoretical framework to analyse the data in a context that elucidates the teaching and learning experiences of pre-service music educators in South African higher education.

\section{Ethical consideration}

Ethical approval to conduct the study was obtained from the ethics committees of the North-West University and University of Pretoria.

\section{Findings and discussion}

From the data collected, three main themes (Figure 2) emerged, which contributed to the proposed model for creating an undergraduate ME curriculum: (1) participants' experiences, (2) Picciano's Blending with purpose multimodal model and (3) ME curriculum.

The following sections discuss these three themes that emerge from data analysis: (1) the participants' comments on how they experienced multimodal teaching and learning; (2) the student-centred pedagogical approaches of ME curriculum; and (3) the way Picciano's Blending with purpose multimodal model connects with the ME curriculum's goals and objectives. 


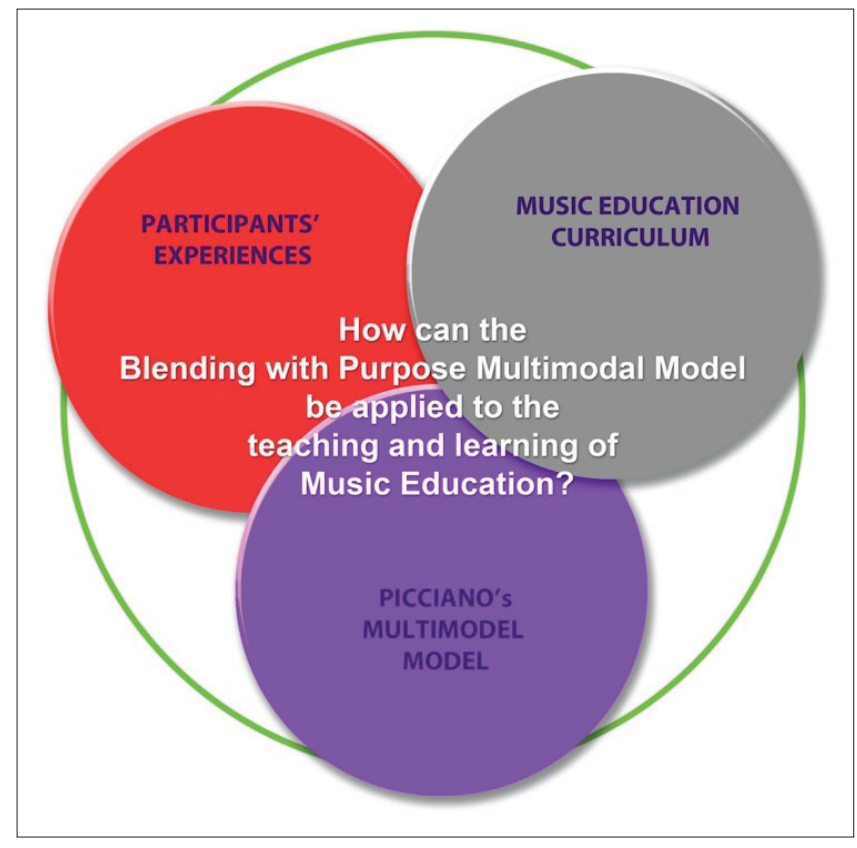

FIGURE 2: Emergent themes.

\section{Theme 1: Participants' experiences}

The music students responded to activities that indicated their learning preferences and learning style. Thuli ${ }^{5}$ mentioned that 'we write out what we study'. Lizette reported that 'with typed notes everything is beautifully organised'. Katherine said: 'I have to study with colours, so instead of wasting four hours with colour pens, I just do it on the computer'. Kim explained that the classroom must be 'calm and very informative'. Alexis indicated that a learning environment should in some sort of way accommodate all students who do learn in different ways. Aileen felt: 'I hate reading with a passion; if I can't see something or hear it, I'm not interested. I get bored so quickly and I miss everything'.

All the students were part of the discipline of ME and the data indicated that, within their diverse learning styles, they also have specific views on teaching and learning through the use of online technologies. Their comments may be related to research conducted by Krätzig and Arbuthnott (2006:241, 242), who supported the idea that each individual uses a diverse 'blend' of learning modalities to learn efficiently and effectively. Jason explained in the following manner:

' $[A]$ n effective learning environment must be balanced, combined with today's various technologies, through interaction with teachers in class and also a more practical online search in class online activities like research.' (Jason, male, 19 years old)

Clara indicated that learning styles differ from one person to another:

'I prefer to learn in an interactive sort of way. If I was sitting in class and was asked to contribute to a discussion, even though it might not be correct, I might have thought about it more and formulate an answer in my head without the information. For me that would stick more than just researching the answer and putting it on the discussion board.' (Clara, female,18 years old).

5.Pseudonyms are used to protect the identity of the participants.
Although the participants represented several cultures, their specific culture made no difference to the way they approached multimodal teaching and learning. They grew up with computers, the Internet and information technologies that are always available (Salajan et al. 2010:1393). According to Krause (2007:138), the 'socio-economic background, age and gender' differences are reflected in their individual experiences of their technological skills and practices. This statement was confirmed by a student from Botswana who had never used a computer before she came to university and struggled to do online assignments at the beginning of her first year. However, she soon developed enough technological skills to work alone and with other class members on online assignments.

Multimodal pedagogy also focuses on learning and learner-centred strategies. The incorporation of blended learning in assignments encouraged students to take more responsibility for their own learning. Some music students did not recognise the value of online technology to enrich their teaching and learning in ME. A few of them were not even concerned about taking responsibility for their own learning of the subject content and skills. They did not even bother to visit the online ME page to locate course information and assignments. The music students who were serious about studying on their own valued instructions without the lecturer's face-to-face assistance. These students navigated the online module page effortlessly, joined in discussion boards and found working in wikis stimulating.

Most music student participants felt that online technology embodies the way they live their lives. However, some students struggled to use online learning activities and they experienced themselves as not really 'technologically advanced'. Jason mentioned that:

' $[A]$ n effective learning environment must be balanced, combined with today's various technologies, through interaction with teachers in class and also a more practical online search in class online activities like research.' (Jason, male, 19 years old)

\section{Theme 2: Music education curriculum}

The analysis of the UP's course study guides indicated that the ME curriculum categories unfolded with studentcentred pedagogical approaches placed within the different 'ways of learning' (Luckett 2001b:31). In the first year, students applied propositional knowledge to carry out challenging new learning activities. Practical competence was embodied throughout the course by creating, performing and listening - students understood the processes of teaching music through practical experiences. Experiential knowledge developed when music students took responsibility of their own learning. They started to engage personally with course outcomes and were able to reflect on music and its significance through understanding music as an approach to give meaning to life experiences. At this level music students started to bridge the gap between just 
knowing and becoming successful music educators. Epistemic knowledge engaged music students in deep, critical thinking about their future as musicians and music teachers. On this level they started to apply constructivist learning principles by planning music learning experiences and so creating a model of musicianship and musical thinking processes.

Students mentioned that new knowledge (propositional knowledge) could be constructed with online activities. Lebogang felt: 'I learned a lot about the topic'; Aileen said that the wiki helped to 'create a reliable source of information'; and Clara explained that the wiki contained 'all the music styles that we learnt about, correctly summarised and all in one area which made it convenient, quick and easy to use'. These experiences signified that problem-solving activities in class allowed students to use different media to realise creative projects. An example of practical knowledge was illustrated when different groups in the class had to do a composing activity - one of the groups decided to use a mobile app to compose a short song. Another group wrote their song on a white board and another one used colourful sticky notes to indicate different tonic solfa levels. Practical proficiency led to the successful application of musical understanding using different learning tools.

The undergraduate ME curriculum also accommodated experiential learning to prepare music students for their future careers. Christelle mentioned that online activities allowed the students to 'actually (apply) what we learned (from ME) in class. We have to incorporate (this) knowledge into a project like teaching examples and stuff'. The thirdyear music students observed and evaluated teaching and learning in the field. Some of the learning outcomes focused on understanding learning and contexts for learning in order to teach for developing musical understanding. The learning outcomes also concentrated on finding a balance between theoretical and practical information through research. The way of knowing in an epistemic knowledge approach requires students to rethink their assumptions about morals, beliefs and social responsibility. Students need to understand the integrated nature of human learning and knowing, consider the importance of a sociocultural, constructive learning process, engage in musical thinking and reflect on the pedagogical strategies they are going to use as music teachers. When students think in systemic and transdisciplinary manner, they see connections between different disciplines and evaluate different theories of knowledge.

Online learning tools allow students to work and communicate during holidays. Roland indicated that students 'can be in separate places and different contexts' to use online tools. Kim mentioned that online interaction could happen 'at their own time', whilst Corlise said: 'it can be done over an extended period of time and can be done anywhere with an Internet connection'. Noah felt that the study material could 'be revisited to study for exams'.

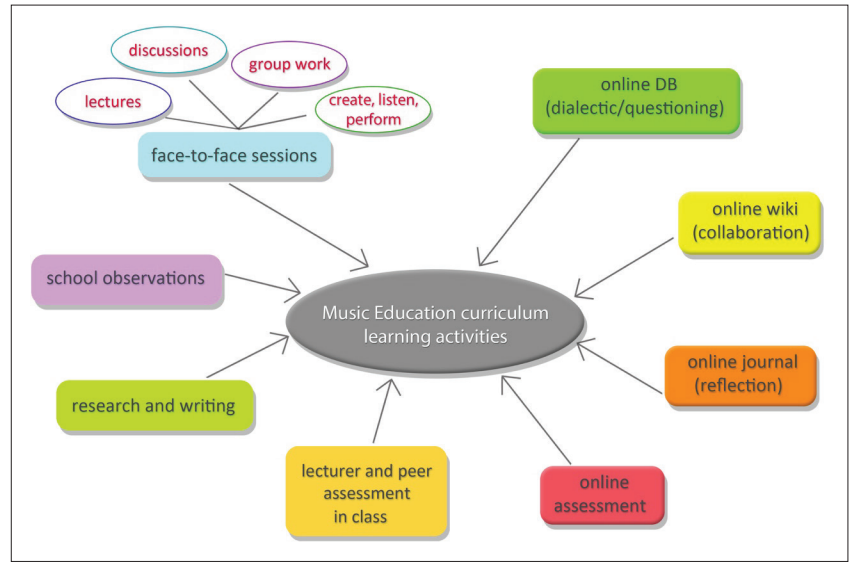

$\mathrm{DB}$, discussion board.

FIGURE 3: Music education curriculum learning activities.

An ME course design should embrace the diversity of music students to create an environment within which they could find their own distinctive learning paths to succeed in their quest to become creative and successful music educators. Figure 3 illustrates current activities that were included in the ME curriculum processes of learning and blending with purpose.

The synthesis of categories that were combined to implement a successful curriculum design was derived from data analysis. The experienced musical life worlds of music students were the point of departure for constructing music curriculum, whilst a holistic teaching philosophy directed course goals and objectives, which were assessed accordingly. The ME curriculum was infused with online technology.

\section{Theme 3: Picciano's Blending with purpose multimodal model}

Music education course goals and objectives determine how the six basic pedagogical objectives/activities of the Blending with purpose multimodal model (content, support, questioning activities, reflection, collaboration and synthesis) support the incorporation of online technologies.

Content: The music students agreed that it was valuable for their learning process to find all course notes online. Thuli stated that students 'don't need to take notes in class and can take in what the lecturer says'.

Social and emotional support: Music students commented that online educational communication cannot give students the one-on-one attention that they may need. Christelle indicated that 'if you are online and you are logged in to someone's lecture, you cannot ask if you have no idea what a word means - you lose that personal touch'. Morgan explained as follows:

' $[W]$ hen you put students in a social situation rather than learning online, we have to perform to prove that we can do what we are supposed to do - if we have online interaction we work at our own pace and might slack down a bit'. 
Dialectic/questioning: Aileen had the following experience:

'[I]n class you don't have time to research and think about a reply or answer. But online I could calmly reply, get my thoughts together and post a collaborative answer - in class it can quickly turn out into an argument'.

Reflection: Online assignments allow students to reflect on the assignments already completed. During the online discussion board in class, some students went back to all the posts and read through the contributions. The journal and blog tools are appropriate collaborative tools for students to reflect upon.

Collaboration/wiki: The wiki is an interactive environment. Alexis mentioned the following:

'[G]enrally, in music, we do our individual instruments where we are only one person. But especially in terms of the wiki,... you get an idea of what other people think and you gain other information that you probably haven't thought about and it adds to your information and what you know and broadens your general knowledge of music by seeing what you've posted and what others have posted - getting the opportunity to see other's opinions - broadens your knowledge as you read it'.

Synthesis/evaluation: Students realised that their research papers and PowerPoint presentations were successfully uploaded online, and that the marks with added comments were available as soon as marking was completed. Thuli said, 'I immediately can see my marks and know exactly what I have done right and where I needed more support'.

\section{Looking at yesterday and tomorrow}

Not much research has been published to establish the outcomes of structuring an entire music curriculum on the values and principles of multimodal teaching and learning. Most studies focus on student opinions on the use of online tools in a learning environment, the implication of single online activities, particular online ME developments, and improvements in the use of online modalities for professional practice.

To expand and support the ME community of inquiry, further research could include the following:

- multimodal experiences of different higher education institutions compared in a multiple case study to identify and propose useful methods of preparing future music educators in South Africa

- a study over an extended period to identify the nature of a sustained practical and effective curriculum

- the integration of online technologies to assist learning in postgraduate modules

- investigating how multimodality could add value to practical music subjects; this research could explore ideas about increasing the learning potential of students and identify online teaching resources from which both students and educators could benefit.

Although designing a new curriculum and experimenting with online activities have had an impact on lecturers' teaching schedules, this endeavour has added value to the ME curriculum. The course goals and objectives were revised and the technologies to enhance multimodal learning were selected more purposefully. The music students were challenged to make use of online modalities to enhance their learning experiences by using new approaches to construct a fuller understanding through multimodal activities in ME.

\section{Model for teaching multimodal music education}

One of the responsibilities of an undergraduate music educator is to structure a curriculum that could support music students in shaping their own identities as musicians and music educators. Figure 4 graphically displays our teaching philosophy which could equip future music teachers to make a difference in South African communities. This could be performed by promoting a lifelong engagement with music by bringing together course learning experiences and musical experiences outside the university, and enabling students to find their own routes into teaching music most effectively.

Pedagogical approaches that affirm this philosophy concentrate on learning and learner-centred strategies. The constructive process of learning (Duffy \& Cunningham 1996:5) is pragmatic and embedded in the previous life experiences of every music student (Wiggins 2015:21). The point of departure for the ME curriculum was students' individual and personal musical understanding formed through diverse lived musical experiences. Biggs (1991:29) explains that students, influenced by their motives for attending a course, create their own learning approach to solve learning problems. Students who experience university as a necessary career opportunity adopt a surface approach to learning. A deep approach focuses on the students' interest in the details of the task. Learning based on the achievement approach concentrates on the self-pride stemming from achieving high grades (Biggs1991:29).

A teaching and learning model, Planning a music education curriculum (Figure 4) was created on the basis of these dynamics to illustrate the diversity of considerations when planning an ME curriculum.

\section{Conclusion}

Picciano's (2009:4-14) Blending with purpose multimodal model outlines the requirements to implement hybrid learning successfully in ME. This conceptual model is flexible and recognises that the learning needs of a wide spectrum of students should be met. Critical to this model is the recommendation that course goals and objectives should be the driving force to determine which pedagogical approaches and technologies should be used. Using this multimodal model also benefits students by encouraging them to use the online technologies that they are familiar with in the course of their everyday lives. 


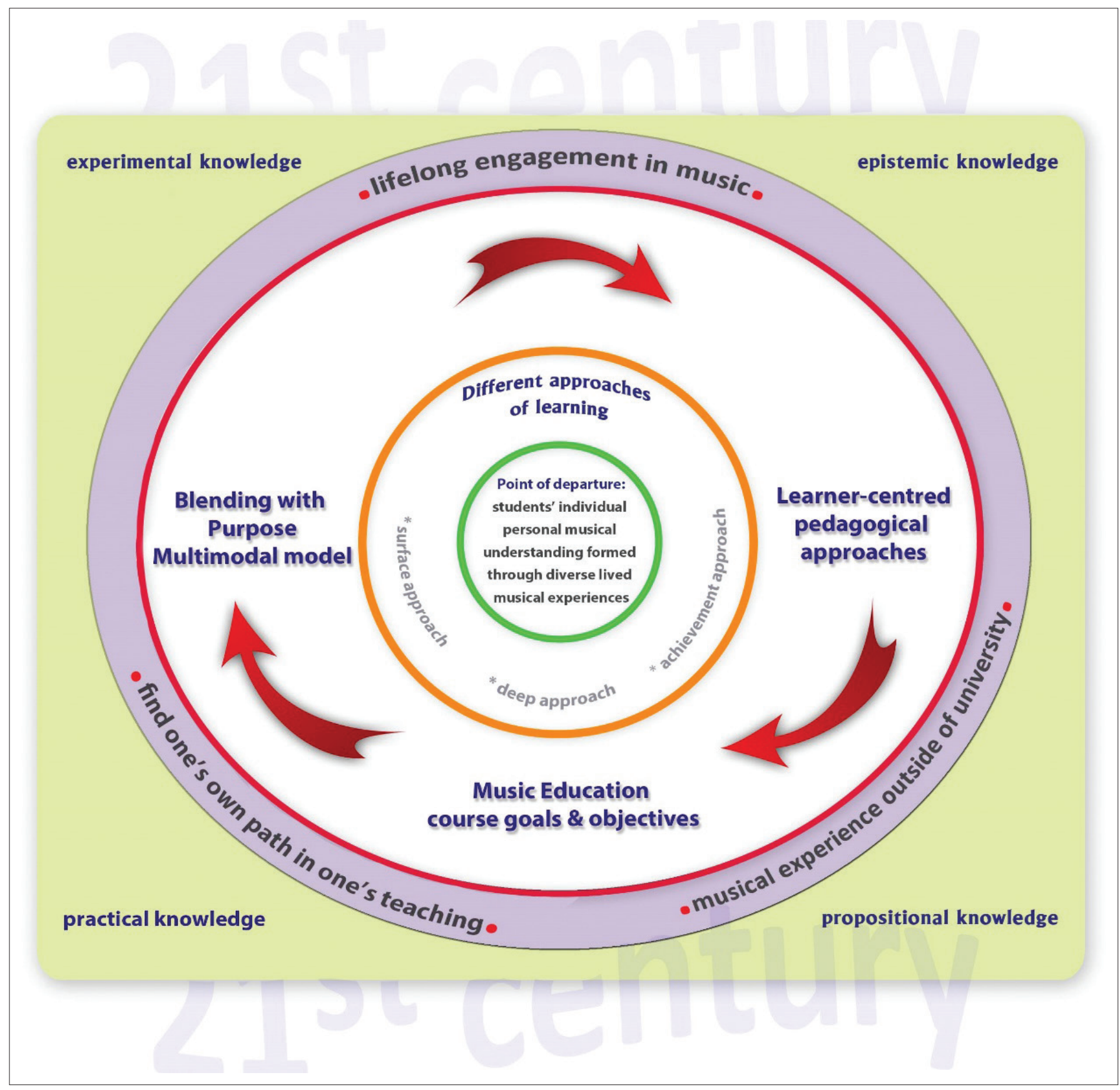

FIGURE 4: Planning a music education curriculum.

\section{Acknowledgements}

The authors declare that they have no financial or personal relationships which may have inappropriately influenced them in writing this article.

\section{Competing interests}

The authors have declared that no competing interest exist.

\section{Author's contributions}

This research was conducted by S.C. with H.P. as the supervisor and co-author. This article is based on a doctoral research conducted by S.C.

\section{Funding information}

This research was supported by the National Research Foundation of South Africa (Unique Grant No.: 93160).

\section{Data availability statement}

Data sharing is not applicable to this article as no new data were created or analysed in this study.

\section{Disclaimer}

Opinions, findings, conclusions and recommendations expressed in this research are those of the authors and the National Research Foundation accepts no liability whatsoever in this regard. 


\section{References}

Barell, J., 2010, 'Problem-based learning: The foundation for 21st century skills', in J.A. Bellanca \& R.S. Brandt (eds.), 21st century skills: Rethinking how students learn, pp. 174-199, Corwin Press, Thousand Oaks, CA.

Bell-Robertson, C.G., 2014, 'Staying on our feet: Novice music teachers' sharing of emotions and experiences within an online community', Journal of Research in Music Education 61(4), 431-451. https://doi.org/10.1177/0022429413508410

Biggs, J.B., 1991, 'Approaches to learning in secondary and tertiary students in Hong Kong: Some comparative studies', Educational Research Journal 6(1), 27-39.

Brändström, S.C., Wiklund, B. \& Lundström, E., 2012, 'Developing distance music education in Arctic Scandinavia: Electric guitar teaching and master classes', Music Education Research 14(4), 448-456. https://doi.org/10.1080/14613808.2 012.703173

Braun, V. \& Clarke, V., 2006, 'Using thematic analysis in psychology', Qualitative Research in Psychology 3(2), 77-101. https://doi.org/10.1191/1478088706qp063oa

Carpenter, J.P. \& Pease, J.S., 2012, 'Sharing the learning', Phi Delta Kappan 94(2), 36-41. https://doi.org/10.1177/003172171209400209

Clarke, V., Braun, V. \& Hayfield, N., 2015, 'Thematic analysis', in J. Smith (ed.) Qualitative psychology: A practical guide to research methods, pp. 222-248, Sage, London.

Creswell, J.W., 2013, Qualitative inquiry \& research design, Kindle edn., Sage, Thousand Oaks, CA, viewed 15 January 2016, from https://www.amazon.com/.

Crosling, G., Heagney, M. \& Thomas, L., 2009, 'Improving student retention in higher education: Improving teaching and learning', Australian Universities Review 51(2), 9-18. https://doi.org/10.4324/9780203935453

Cruywagen, S., 2015, “'Blending with purpose”: A multimodal model for music education', PhD thesis, North-West University, Potchefstroom.

Digolo, B.A., 2012, 'Availability and use of teaching and learning resources for music education in Kenya: A survey of secondary schools in Nairobi province', Doctoral dissertation in Music, Kenyatta University, Nairobi.

Duffy, T.M. \& Cunningham, D.J., 1996, 'Constructivism: Implications for the design and delivery of instruction', in R.A. Braden (ed.), Handbook of research for educational communications and technology, pp. 170-198, Macmillan, New York.

Dunbar-Hall, P., 2011, 'Children's learning of music and dance in Bali: An ethnomusicological view of the cultural psychology of music education', in M.S. Barrett (ed.), A cultural psychology of music education, pp. 17-40, Oxford University Press, New York.

Garrison, D.R. \& Kanuka, H., 2004, 'Blended learning: Uncovering its transformative potential in higher education', Internet and Higher Education 7(2), 95-105. https://doi.org/10.1016/j.iheduc.2004.02.001

Graham, C.R., 2005, 'Blended learning systems: Definition, current trends, and future directions', in C.J. Bonk \& C.R. Graham (eds.), The handbook of blended learning: Global perspectives, local designs, pp. 3-21, Pfeiffer, San Francisco, CA.

Harper-Scott, J.P.E. \& Samson, J., 2009, An introduction to music studies, Cambridge University Press, New York.

Howie, S.J. \& Pietersen, J.J., 2001, 'Mathematics literacy of final year students: South African realities', Studies in Educational Evaluation 27(1), 7-25. https://doi. org/10.1016/S0191-491X(01)00011-6

Jaffer, S., Ng'ambi, D. \& Czerniewicz, L., 2007, 'The role of ICTs in higher education in South Africa: One strategy for addressing teaching and learning challenges', International Journal of Education and Development Using ICT 3(4), 131-142.

Jonassen, D.H., 1999, 'Designing constructivist learning environments', in C.M. Reigeluth (ed.), Instructional design theories and models: A new paradigm of instructional theory, pp. 215-239, Erlbaum, Mahwah, NJ.

Kimpton, J., 2005, 'What to do about music teacher education: Our profession at a crossroads', Journal of Music Teacher Education 14(2), 8-21. https://doi.org/10.1 $177 / 10570837050140020103$

Komarraju, M., Karau, S.J., Schmeck, R.R. \& Avdic, A., 2011, 'The big five personality traits, learning styles, and academic achievement', Personality and Individual Differences 51(4), 472-477.

Krätzig, G.P. \& Arbuthnott, K.D., 2006, 'Perceptual learning style and learning proficiency: A test of the hypothesis', Journal of Educational Psychology, 98(1): 238.

Krause, K.L.D., 2007, 'Who is the e-generation and how are they faring in higher education', in J. Lockard \& M. Pegrum, (eds.), Brave new classrooms: Educational democracy and the internet, pp.125-140, Peter Lang, New York.
Le Rossignol, K., 2014, 'Designing blended learning: Transformative scenarios for the millennial learner', in J.H. Westover \& J.P. Westover (eds.), Engaging hybrid and blending learning in higher education, pp. 1-16, Canadian Center of Science and Education, Common Ground, Richmond Hill.

Liaw, S.S., Huang, H.M. \& Chen, G.D., 2007, 'Surveying instructor and learner attitudes toward e-learning', Computers \& Education 49(4), 1066-1080. https://doi. org/10.1016/j.compedu.2006.01.001

Long, P.D., 2005, 'Learning space design in action', Educause Review 40(4), 60.

Luckett, K., 2001a, 'A proposal for an epistemically diverse curriculum for South African higher education in the 21st century', South African Journal of Higher Education 15(2), 49-61. https://doi.org/10.4314/sajhe.v15i2.25354

Luckett, K., 2001b, 'Responding to equity and development imperatives: Conceptualizing a structurally and epistemically diverse undergraduate curriculum in post-apartheid South Africa', Equity \& Excellence in Education 34(4), 26-35. https://doi.org/10.1080/1066568010340304

Merritt, S., 2002, 'Learners of the future', International Journal of Construction Education and Research, paper presented at the Faculty Development Institute sponsored by Villanova University and the National League for Nursing, Villanova, PA.

Modisaotsile, B.M., 2012, The failing standard of basic education in South Africa, Briefing No. 72, African Institute of South Africa, Pretoria.

Morford, J.B., 2007, 'Constructivism: Implications for postsecondary music education and beyond', Journal of Music Teacher Education 16(2, Spring), 75-83. https://doi org/10.1177/10570837070160020108

Naughton, C., 2012, "Heidegger and Joe: Revisiting the "thing" in the context of a student's experience of an online community', British Journal of Music Education 29(3), 331-341. https://doi.org/10.1017/S0265051712000307

Oblinger, D. \& Oblinger, J., 2005, 'Is it age or IT: First steps toward understanding the net generation', in D. Oblinger, J. Oblinger \& J. Boulder (eds.), Educating the net generation, loc. 2.1-2.20, Educause, Washington, DC.

Paechter, M. \& Maier, B., 2010, 'Online or face-to-face? Students' experiences and preferences in e-learning', Internet and Higher Education 13(4), 292-297. https:// doi.org/10.1016/j.iheduc.2010.09.004

Partti, H., 2014, 'Cosmopolitan musicianship under construction: Digital musicians illuminating emerging values in music education', International Journal of Music Education 32(1), 3-18. https://doi.org/10.1177/0255761411433727

Picciano, A.G., 2009, 'Blending with purpose: The multimodal model', Journal of the Research Center for Educational Technology 5(1), 4-14.

Picciano, A.G., 2014, A critical reflection of the current research in online and blended learning, viewed 07 June 2015, from https://www.elmmagazine.eu/ learning, viewed 07 June 2015, from https://www.elmmagazine.eu/

Reimer, B., 2007, 'Comprehensive education, comprehensive music education: A new vision', Music Education Research International 1(1), 1-12.

Rovai, A.P. \& Jordan, H., 2004, 'Blended learning and sense of community: A comparative analysis with traditional and fully online graduate courses', The International Review of Research in Open and Distributed Learning 5(2), 1-13. https://doi.org/10.19173/irrodl.v5i2.192

Salajan, F.D., Schönwetter, D.J. \& Cleghorn, B.M., 2010, 'Student and faculty intergenerational digital divide: Fact or fiction?', Computers \& Education 55(3), 1393-1403. https://doi.org/10.1016/j.compedu.2010.06.017

Scott, S.J., 2012, 'Constructivist perspectives for developing and implementing lesson plans in general music', General Music Today 25(2), 24-30. https://doi. org/10.1177/1048371311398285

Singh, A., 2014, 'Challenges and issues of generation Z', Journal of Business and Management 16(7), 59-63. https://doi.org/10.9790/487X-16715963

Spronken-Smith, R., 2007, 'Experiencing the process of knowledge creation: The nature and use of inquiry-based learning in higher education', Journal of Geography in Higher Education 2, 183-201.

Vajoczki, S., Watt, S., Vine, M.M. \& Liao, R., 2011, 'Inquiry learning: Level, discipline, class size, what matters?', International Journal for the Scholarship of Teaching and Learning 5(1), 10. https://doi.org/10.20429/ijsotl.2011.050110

Valiathan, P., 2002, 'Blended learning models', Learning Circuits 3(8), 50-59.

Wiggins, J., 2007, 'Authentic practice and process in music teacher education' Music Educators Journal 93(3), 36-42. https://doi.org/10.1177/0027432107093 00318

Wiggins, J., 2015, Teaching for musical understanding, Oxford University Press, New York.

Yin, R.K., 2009, Case study research, Kindle edn., Sage, Thousand Oaks, CA. 